John Carroll University

Carroll Collected

Economics \& Finance

1993

\title{
Common Stock Price Effects of Security Issues Conditioned by Current Earnings and Dividend Announcements
}

Timothy A. Manuel

LeRoy D. Brooks

John Carroll University, lbrooks@jcu.edu

Frederick P. Schadler

Follow this and additional works at: http://collected.jcu.edu/econ_fin-facpub

Part of the Economics Commons, and the Finance and Financial Management Commons

\section{Recommended Citation}

Manuel, Timothy A.; Brooks, LeRoy D.; and Schadler, Frederick P., "Common Stock Price Effects of Security Issues Conditioned by Current Earnings and Dividend Announcements" (1993). Economics \& Finance. 7.

http://collected.jcu.edu/econ_fin-facpub/7 


\section{Common Stock Price Effects of Security Issues Conditioned by Current Earnings and Dividend Announcements}

\section{Introduction}

Models of corporate and investor behavior by Myers and Majluf (1984) John and Williams (1985), Miller and Rock (1985), and Korajczyk, Lucas, and McDonald (1991) provide theoretical support for a relationship between the announcement effect of a common stock issue and information released by current period dividends or earnings announcements. Disclosure models by Verrecchia (1990) and an earnings timing model discussed in Trueman (1990) also lead to possible timing behavior around security offerings. These studies hypothesize that the firms' announcements change the information set available to equity investors, resulting in reevaluation of the firm's stock price.

The first goal of this article is to determine whether investors react differently to a security issue announcement that closely precedes earnings and dividend information versus offer announcements made recently after dividend and earnings releases. A corollary aim is to determine whether some managers time equity or debt

(Journal of Business, 1993, vol. 66, no. 4)

(C) 1993 by The University of Chicago. All rights reserved. $0021-9398 / 93 / 6604-0003 \$ 01.50$
The valuation effect of debt and equity issue announcements on stock price varies predictably with the timing of earnings and dividend reports. Issue announcements closely preceding current cash flow signals have more negative valuation effects. Straight debt announcements also have a significantly negative effect on stock pricẹ when the offer announcement closely precedes earnings and dividend releases. The evidence is consistent with a separating equilibrium where better performing firms signal superior value by announcing equity offers shortly after dividend announcements. Poorer performers appear to time equity offers just before dividend signals, which in turn are more likely to be negative. 
issue announcements to occur soon after favorable periodic (quarterly) announcements while other managers announce issues before release of unfavorable periodic information. The occurrence of either phenomenon would support the central objective of this article: to examine whether a separating equilibrium between better and poorer performing companies may exist.

This study draws on and extends similar empirical work by Korajczyk, Lucas, and McDonald (1991) and Dierkens (1991). Korajczyk, Lucas, and McDonald (1991) (KLM) show that the equity issue announcement price decline is directly related to the amount of information asymmetry. Consequently, firms are more likely to issue equity when information asymmetry is lowest. This condition occurs immediately after an informative announcement, such as earnings. The longer the elapsed time since the last information release, the greater the potential information asymmetry. This implies that the price decline at an equity issue announcement date is an increasing function of the time in days since the last regular quarterly earnings announcement. In the KLM framework, the longer the time since the last earnings release, the more likely the issuing firm is of lower quality. They find a statistically weak linear relationship between the equity announcement abnormal return and the interval since the last earnings release. We document a stronger relationship between the price response of an equity issue announcement and the availability of prior dividend and earnings information. We also show that common stock abnormal returns associated with straight debt offer announcements reflect the timing of the firm's earnings and dividend announcements. Abnormal returns for straight debt offerings are significantly different from zero only when the offer announcement is not closely preceded by the earnings and dividend announcements. ${ }^{1}$

Dierkens (1991) also finds that the price decrease associated with an equity issue is directly related to various measures of information asymmetry. Since the level of asymmetry may be reduced by earnings releases that closely precede equity offers, a clustering of security offer announcements would be expected shortly after current earnings announcements. Both Korajczyk, Lucas, and McDonald and Dierkens find this phenomenon. Also, Dierkens reports that firms with greater information asymmetry are more likely to issue equity soon after an

1. Myers and Majluf (1984) predict an insignificant abnormal return for announcements of riskless debt offerings and a negative abnormal return for risky debt. Previous research has generally not supported the prediction for risky straight debt. Our results are also consistent with Kross and Schroeder (1984) and Penman (1987), who report that investors revise earnings expectations downward when managers delay announcement of unfavorable earnings. Asquith and Mullins (1986), Eckbo (1986), Masulis and Korwar (1986), Mikkelson and Partch (1986), and Kalay and Shimrat (1987) document the effect of security issues on stock value. 
earnings release. Both studies find that earnings announcements preceding an equity issue are more informative than earnings announcements following an equity issue. We document similar clustering of both debt and equity offer announcements after dividend and earnings releases; however, we find no differences in the informativeness of pre- versus postissue earnings. This result is consistent with Healy and Palepu (1987, 1990), who find no relationship between equity offer announcements and subsequent changes in earnings. Brous (1992) also reports that equity announcements do not signal a downward revision in analysts' earnings forecasts. Alternatively, Hansen and Crutchley (1990) show that external financing announcements signal long-term earnings declines.

The predictions of the KLM and Dierkens models should hold with any information release, though their empirical tests consider only the effect of earnings announcements. The current study considers the conditioning effect of both dividend and earnings releases on equity and debt offer announcements. ${ }^{2}$ Equity and debt offer abnormal returns are more negative for longer intervals between the offer announcement and the prior release of dividend information. Subsequent dividend changes are more likely to be negative when equity (but not debt) issue announcements are more distant from prior dividend announcements. These results are consistent with managerial timing and investors' reactions provided by Kalay and Loewenstein (1985), who show that managers tend to postpone decreases in dividends. Abnormal returns for equity offer announcements are not affected by the timing of the earnings release. Thus, the equity issue announcement timing appears to contain a dividend information effect but not an earnings information effect. Korajczyk, Lucas, and McDonald's finding of an earnings effect may reflect the dividend phenomenon since they did not specifically control for dividends. Consistent with their earnings information effect, we do find a significant earnings release effect of the appropriate sign with debt issues.

Our results support the implications of the John and Williams (1985) model, where higher-quality firms signal their value by paying larger dividends. The dividend payment signals the firm's true value, resulting in a higher stock price. ${ }^{3}$ This model implies that security issue

2. Ball and Brown (1968) and Rendleman, Jones, and Latane (1982) show a direct relationship between common stock price changes and the announcement of unexpected earnings. Charest (1978), Aharony and Swary (1980), Kwan (1981), Asquith and Mullins (1983), Brickley (1983), Handjinicolaou and Kalay (1984), Fehrs, Benesh, and Peterson (1988), and Lang and Litzenberger (1989) support the information content of dividend announcements. Kane, Lee, and Marcus (1984) provide evidence of signaling interactions between earnings and dividends announcements.

3. Also see Ambarish, John, and Williams (1987). For our purposes, either model yields similar implications. 
announcements with distant prior dividend releases are likely to be less well received than issue announcements that closely follow "good" dividend signals. Loderer and Mauer (1992) test this implication by examining managerial timing of equity announcements relative to the dividend announcement. They find that firms issuing equity are not more likely to pay a dividend than nonissuing firms. Their sample tests also show that firms tend to issue equity after dividend announcements rather than before, but they argue that this may be coincidental. Loderer and Mauer (1992) find no association between the timing of the dividend announcement and the equity announcement abnormal return. They also find no relationship between the sign of Miller and Rock's (1985) net dividend and the equity announcement date abnormal return. Hence, they interpret their work as providing little support for either the John and Williams or the Miller and Rock models.

The current study finds a more negative issue announcement valuation effect when the offer announcement closely precedes the current period dividend announcement. Negative dividend changes also occur more frequently when the equity offer announcement precedes the dividend release. We do not directly test the appropriateness of specific signaling models or attempt to distinguish between them. A general implication of several signaling models is examined on whether investor's offer announcements reactions differ in a predictable manner when information asymmetry levels differ between investors and managers.

Section II provides hypotheses concerning the conditional signaling environment tested. Section III outlines the sample selection procedure, methodology, and descriptive statistics of the samples. Section IV presents the results for both the stock and debt sample and examines differences in earnings and dividend changes based on signal sequence. Section V concludes the article. An Appendix outlines the nature of revealing signals in a simple Miller and Rock (1985) framework.

\section{Testable Implications of the Effect of Signal Sequence}

The information effect of a given signal is a function of the signal content and (we hypothesize) the signal's sequence relative to the announcement of other information releases. We test whether releasing the earnings and dividend information to the public shortly before the offer announcement changes how investors interpret the announcement of a security offering. Whether or not the effect of signal sequence is significant is an open empirical question. If dividend, earning, and security issue signals partially reveal each other, the information content of a subsequent signal will be related to (1) the unexpected signal content, (2) the sequence of release in the set of 
signals, and (3) the elapsed time interval since the release of prior signals. Tests used by Korajczyk, Lucas, and McDonald (1991) implicitly assume that inside information is received uniformly over time by managers. Thus, the relationship between the time interval between fully (or partially) revealing signals and the information content of the subsequent signal would be linearly related. The primary methodology of this study avoids this potentially limiting assumption.

Earnings and dividend signals for dividend paying firms occur regularly through time. A security issue announcement, thereby, both precedes and follows these other signals. However, managers can time the security issue announcement relative to these regularly announced signals. An operational definition of "signal sequencing" is used in this study to capture this timing relationship. If the chronologically closest earnings (dividend) announcement in the time series of such announcements is prior to the security issue announcement, the earnings (dividend) announcement is defined as a prior announcement. If the chronologically closest earnings or dividend announcement to the security issue announcement is after the security announcement, the earnings (or dividend) announcement is defined as occurring after the issue announcement.

There are eight possible combinations of the sequence of announcements considered in this study. To simplify the analysis, the four portfolios presented in table 1 are formed. Portfolio 1 consists of observations where the announcement of earnings $(X)$ and dividends $(D)$ precedes the security $(B)$ announcement. This portfolio includes three possible chronological sequences, $(X-D-B),(D-X-B)$, and ( $[X D]$ $-B$ ), where the brackets enclose simultaneous announcements. ${ }^{4} \mathrm{We}$ hypothesize that the $X$ and $D$ signals in this portfolio are partially revealing of $B$, and the absolute value of the observed abnormal return associated with $B$ is reduced by the preceding signals.

Portfolio 2 consists of the sequence $(X-B-D)$ where the earnings announcement precedes the offer announcement and the dividend announcement follows the offer announcement. If earnings completely reveal $B$ as in the single-period model of Miller and Rock (1985), the average security announcement effects observed for portfolios 1 and 2 should be identical since in both cases $X$ precedes $B$. If $D$ contains information about $B$ not revealed by $X$, the informativeness of $B$ in portfolio 2 may be larger than in portfolio 1 since in 2 the information

4. Observations with multiple events on the security announcement date are eliminated. Thus, the combinations excluded contain $\left(\left[\begin{array}{lll}X & D\end{array}\right]\right),\left(\left[\begin{array}{ll}X & B\end{array}\right]-D\right),(D-[X B])$, $([D B]-X)$, and $(X-[D B])$. In each of these combinations, the marginal informativeness of $B$ is unobtainable due to the simultaneous occurrence of at least one other signal. In addition, the sequences $[(B-X-D)$ and $(B-D-X)]$, as well as $[(X-D-B)$ and $(D-$ $X-B)]$, are considered equivalent since only the effect of the combination of $X$ and $D$ on $B$ is examined. 
TABLE 1 Portfolio Partitions by Sequence of Events

\begin{tabular}{lcc}
\hline & $D$ Precedes $B$ & $D$ Follows $B$ \\
\hline$X$ precedes $B$ & Portfolio 1 & Portfolio 2 \\
Sequences* & $(X-D-B)$ & $(X-B-D)$ \\
& $([X D]-B)$ & \\
Relative effect on $B$ & $(D-X-B)$ & $B$ partially \\
& $B$ partially & revealed by $X$ \\
$X$ follows $B$ & revealed by $X$ and $D$ & Portfolio 4 \\
Sequences* & Portfolio 3 & $(B-X-D)$ \\
& $(D-B-X)$ & $(B-D-X)$ \\
Relative effect on $B$ & & $(B-[X D])$ \\
& $B$ partially & No prior signal \\
& revealed by $D$ & reveals B
\end{tabular}

NoTE.-Relative hypothesized security announcement effects are separated into four portfolios based on different levels of expected information that result from the sequence of partially revealing adjacent announcements of earnings and dividends. The sequences are given in chronological order. Thus, $(X-D-B)$ indicates that the earnings announcement $(X)$ precedes the dividend announcement $(D)$, while the dividend announcement also precedes the security issue announcement $(B)$. The brackets enclose simultaneous announcements.

* Sequences are omitted that include at least one other signal released simultaneously with $B$ since in this case our empirical tests are unable to distinguish the relative informativeness of $B$.

in $D$ is not yet revealed. This result would be consistent with the predictions of John and Williams (1985). ${ }^{5}$

Portfolio 3 consists of the sequence $(D-B-X)$. In this case $D$ partially reveals $B$, but information about earnings is not yet available. If dividends are less revealing of $B$ than $X$, the information content of $B$ should be greater in portfolio 3 than either portfolio 1 or 2 since in portfolios 1 and 2 the earnings information is already public. If $X$ and $D$ are equally revealing of $B$, the information content of $B$ in 1,2 , and 3 should be identical, ceteris paribus. Finally, in portfolio $4, B$ precedes both $X$ and $D$. The possible sequences include $(B-X-D),(B-D-X)$, and $\left(B-\left[\begin{array}{ll}X & D\end{array}\right]\right)$. Since no other announcement has occurred to reveal $B$, the absolute value of the abnormal return of $B$ should be unambiguously greater for portfolio 4 than any of the other three portfolios.

\section{Sample and Methodology}

\section{A. Sample Selection}

The firms selected for the sample were obtained from the Registered Offering Statistics (ROS) tape compiled by the Securities and Exchange Commission (SEC). All common stock and straight debt issues from 1971 through part of 1986 were initially considered. Announce-

5. In another test (unreported), no evidence of a relationship between relative offer size and abnormal returns was found. Therefore, the size variable was omitted in further analysis. This is consistent with Dierkens's (1991) results. 
ment dates for security issues are the earlier of (i) the day the security is registered with the SEC or (ii) the day the issue appears in the Wall Street Journal, as announced in the Wall Street Journal Index. Because of the uncertainty in precisely identifying when the market receives the news, the standard 2-day event period is used, consisting of days -1 and 0 . All issue announcements from the ROS tape were verified with the Wall Street Journal Index. The following additional screens are applied.

1. The issue is for straight debt or common stock and must be the only registration filed by the firm on that date.

2. The issue is an immediate cash offering to the public. Thus, shelf registrations and registrations for other special purposes such as conversions and employee stock option plans (ESOPs) are eliminated.

3. Only unregulated firms are included. Firms identified on the ROS tape as financial institutions, utilities, and natural gas and oil are omitted since managers of regulated firms often may not have complete control over capital structure decisions.

4. The firm must be on the Center for Research in Security Prices (CRSP) Daily Return Tape for 55 trading days before the announcement of the issue and remain on the tape for 140 trading days following the issuance date.

5. No other significant firm announcements occurred during the 2-day event period. Other announcements are found in the Wall Street Journal Index and include major contracts, merger statements, management changes, and so on. ${ }^{6}$

6. The offering must have been completed. In our samples, the number of withdrawn offerings is too small to allow meaningful analysis of these observations.

7. Both a dividend and earnings announcement must occur within $2 \frac{1}{2}$ months, plus or minus, from the issue announcement date. Initially, the closest dividend and quarterly earnings announcement date to the issue announcement are used. The $2^{1 / 2}$-month restriction provides a weak constraint in excluding adjacent earnings and dividends that are too distant to affect or be affected by the issue announcement. Dividends are obtained from the CRSP Monthly Master Tape, Moody's Dividend Record, or the Wall Street Journal Index. Quarterly earnings information comes from COMPUSTAT, the Wall Street Journal Index, or Moody's Handbook of Common Stock.

6. Results are also replicated after screening the Wall Street Journal Index to eliminate stock repurchases and debt buybacks in the quarter of security issue and in the quarter before and after the issue quarter. The results are not materially changed and are not reported. 


\section{B. Methodology}

The information signaled by external financing announcements also may be a function of the size of the adjacent signals (see Miller and Rock 1985). Thus, simple measures of signal size or strength are used in the analysis. Unexpected changes in dividends $\left(D^{u}\right)$ are calculated based on the naive model shown by Kwan (1981) to perform well as a forecast of dividend expectations,

$$
D^{u}=D_{q} / D_{q-1},
$$

where $D_{q}$ is the quarterly dividend nearest to the security issue announcement. Dividends are adjusted for splits and stock dividends. Division by zero is not a problem since all sample firms have positive dividends for the $q-1$ period. Unexpected earnings $\left(X^{u}\right)$ are also obtained with a naive model,

$$
X^{u}=X_{q} / X_{q-1},
$$

where $X_{q}$ is the quarterly earnings nearest to the security issue announcement. The absolute value of $X_{q-1}$ is used in the few cases where $X_{q-1}$ is negative. Tests rederived with these observations omitted provide qualitatively similar results.

Abnormal returns are generated via a market model using standard event-study methodology similar to Mikkelson and Partch (1986). Because of the use of a 2-day event period, all time intervals in the estimation period are also 2-day periods. ${ }^{7}$ Each abnormal return is treated as a prediction error and standardized according to Johnston (1984). Tests of differences of portfolio average standardized prediction errors (ASPEs) between portfolios 1 through 4 are conducted using a simple dummy variable regression on the portfolio partitions. For example, to determine whether ASPE $_{1}$ from portfolio 1 differs from $\mathrm{ASPE}_{4}$ for portfolio 4, the following regression is estimated,

$$
\mathrm{SPE}_{i}=\alpha+\beta b_{j i}+e_{j i},
$$

where observation $i$ is in either portfolio $j=1$ or 4 . The value $\mathrm{SPE}_{i}$ is the standardized prediction error for observation $i$, and $b_{j i}$ is a binary indicator variable equal to one when observation $i$ is drawn from portfolio $j=1$ and equal to zero if the observation is from portfolio $j=$ 4. The value $\mathrm{ASPE}_{4}$ is given by $\alpha$ in equation (3). If the beta is significant, $\mathrm{ASPE}_{1}$ statistically differs from $\mathrm{ASPE}_{4}{ }^{8}$ The analysis is repeated for both the debt and equity samples for all possible pairs of portfolio combinations, yielding six comparisons per sample.

7. Two-day intervals are used to assure that the expected value of the residual is zero conditional on no announcement.

8. The test of the significance of beta is a two-tailed test. Adjusted $p$-values reflect the one-sided nature of our hypothesis in the abnormal returns (AR) comparisons where there are unambiguous predictions of the relative size of the AR. 


\section{Sample Description and Demographics}

The final sample consists of 579 straight debt offerings and 191 common stock offerings. The distributions of offerings per year for the initial and screened samples are provided in table 2. The 2-day mean prediction error (unstandardized) for the equity issue sample is $-2.84 \%$ and is significant at the $1 \%$ level..$^{9}$ The mean prediction error of $-0.17 \%$ for the debt sample is not significant at the $10 \%$ level. These findings are consistent with prior research where equity issue announcements result in negative abnormal returns of about $-3 \%$ and straight debt issue announcements result in an insignificant mean abnormal return.

The mean dividend change for the stock sample is $-1.74 \%$ (significant at the $1 \%$ level), while the average dividend change is $1.87 \%$ for the debt sample (significant at the $10 \%$ level). The average earnings change for the stock sample is $9.20 \%$ (significant at the $1 \%$ level), while the mean earnings change in the debt sample is $1.60 \%$ (insignificant). Thus, stock issues on average appear to have a contemporaneous decrease in dividends and an increase in earnings. Earnings increases in prior periods were not examined, precluding conclusions on whether earnings changes are different from expectations. However, since dividend decreases are uncommon (Eades, Hess, and Kim 1985), the mean dividend decrease for the equity sample probably does represent an unexpected change.

Table 3 contains sample sizes for the four portfolio partitions. In both the stock and debt samples, the majority of observations, $39.3 \%$ and $42.7 \%$, respectively, are found in portfolio 1 , where earnings and dividends precede security issue announcements. A one-way chisquare test for both the stock $\left(\chi^{2}=13.248, p\right.$-value $\left.<.01\right)$ and debt $\left(\chi^{2}=54.045, p\right.$-value $\left.<.01\right)$ issue samples rejects the null of equal portfolio size over the four portfolios. There is some clustering of both types of external financing announcements after information releases. Loderer and Mauer (1992) point out that this does not necessarily imply managers voluntarily time security issues relative to earnings and dividend announcements for signaling reasons. The earnings, dividend, and issue decisions are often collectively made at a quarterly meeting of the board of directors. They argue that the issue process may require postponing the issue announcement until terms are finalized, while there may be no reason to delay the earnings and dividend announcements.

9. All tests of statistical significance involving the security announcement abnormal returns employ standardized prediction errors. For ease of interpretation, the associated unstandardized prediction errors are reported. Abnormal returns on both samples are also obtained using 1-day intervals over the estimation period. Both a 55-day preannouncement period and a 140-day postannouncement estimation period are used. No material change in the results occurred. 
TABLE 2 Number of Offerings by Year in the Preliminary and Final Samples

\begin{tabular}{|c|c|c|c|c|}
\hline \multirow[b]{2}{*}{ Year } & \multicolumn{2}{|c|}{ Straight Debt Offers } & \multicolumn{2}{|c|}{ Common Stock Offers } \\
\hline & Preliminary & Final & Preliminary & Final \\
\hline 1971 & 62 & 48 & 85 & 34 \\
\hline 1972 & 28 & 22 & 50 & 15 \\
\hline 1973 & 17 & 14 & 7 & 3 \\
\hline 1974 & 47 & 33 & 6 & 4 \\
\hline 1975 & 75 & 58 & 17 & 8 \\
\hline 1976 & 40 & 36 & 31 & 17 \\
\hline 1977 & 31 & 19 & 10 & 6 \\
\hline 1978 & 41 & 24 & 22 & 8 \\
\hline 1979 & 36 & 19 & 19 & 15 \\
\hline 1980 & 86 & 67 & 29 & 16 \\
\hline 1981 & 48 & 34 & 21 & 13 \\
\hline 1982 & 101 & 77 & 14 & 8 \\
\hline 1983 & 55 & 34 & 50 & 35 \\
\hline 1984 & 41 & 25 & 8 & 4 \\
\hline 1985 & 60 & 43 & 4 & 4 \\
\hline $1986^{*}$ & 32 & 26 & 2 & 1 \\
\hline Total & 800 & 579 & 375 & 191 \\
\hline
\end{tabular}

* The number of 1986 issues is small because the Registered Offering Statistics tape available for this project does not include all 1986 registrations.

TABLE 3 Sample Size of Each Portfolio Partition

A. Common Stock Offers

\begin{tabular}{lccc}
\hline & $D$ Precedes $B$ & $D$ Follows $B$ & Row Total \\
\hline$X$ precedes $B$ & Portfolio 1 & Portfolio 2 & \\
& 75 & 38 & 113 \\
& $(39.27 \%)$ & $(19.90 \%)$ & $(59.16 \%)$ \\
$X$ follows $B$ & Portfolio 3 & Portfolio 4 & \\
& 31 & 47 & 78 \\
& $(16.23 \%)$ & $(24.61 \%)$ & $(40.84 \%)$ \\
Column total & 106 & 85 & 191 \\
& $(55.50 \%)$ & $(44.50 \%)$ & \\
\hline
\end{tabular}

B. Straight Debt Offers

\begin{tabular}{lccl}
\hline & $D$ Precedes $B$ & $D$ Follows $B$ & Row Total \\
\hline$X$ precedes $B$ & Portfolio 1 & Portfolio 2 & \\
& 247 & 93 & 340 \\
$X$ follows $B$ & $(42.66 \%)$ & $(16.06 \%)$ & $(58.72 \%)$ \\
& Portfolio 3 & Portfolio 4 & \\
& 101 & 138 & 239 \\
Column total & $(17.44 \%)$ & $(23.83 \%)$ & $(41.28 \%)$ \\
& 348 & 231 & 579 \\
& $(60.10 \%)$ & $(39.90 \%)$ & \\
\hline
\end{tabular}

Note.-Panel A consists of the breakdown of the stock sample into portfolios 1 through 4. Panel B presents a similar breakdown for the debt issue sample. The percentage of the total sample constituted by the given category is presented in parentheses beneath the sample sizes. 
For both samples, portfolio 4 contains the next highest proportion of observations, where both earnings and dividends occur after the security issue announcement. The larger number of observations in portfolios 1 and 4 is not surprising since earnings and dividend announcements are usually clustered and released after scheduled board meetings.

\section{Results}

\section{A. Signal Sequence and Equity Announcement Abnormal Returns}

The mean abnormal returns (ARs) for the four stock issue portfolios are presented in panel A of table 4. Each of the four portfolio ARs are negative and significant. The negative ARs range from an absolute minimum of $-2.11 \%$ for portfolio 3 to an absolute maximum of

TABLE 4 Average Prediction Errors for Equity Offers by Portfolio

A. Portfolio Mean Abnormal Returns: Equity Offers

\begin{tabular}{lcc}
\hline & $D$ Precedes $B$ & $D$ Follows $B$ \\
\hline$X$ precedes $B$ & Portfolio 1 & Portfolio 2 \\
Mean abnormal return (AR) & $-.0252^{* *}$ & $-.0317^{* *}$ \\
$X$ follows $B$ & Portfolio 3 & Portfolio 4 \\
Mean abnormal return (AR) & $-.0211^{* *}$ & $-.0359^{* *}$ \\
\hline
\end{tabular}

B. Comparisons of Portfolio Mean Abnormal Returns: Equity Offers

\begin{tabular}{|c|c|c|c|}
\hline & \multicolumn{3}{|c|}{ Portfolio Comparisons } \\
\hline & $1-2$ & $1-3$ & $1-4$ \\
\hline \multirow[t]{3}{*}{$D{\text { [mean abnormal return }]^{\mathrm{b}}}^{\mathrm{b}}$} & -.0065 & .0041 & $-.0107^{*}$ \\
\hline & \multicolumn{3}{|c|}{ Portfolio Comparisons } \\
\hline & $2-3$ & $2-4$ & $3-4$ \\
\hline$D$ [mean abnormal return $]$ & .0106 & -.0042 & $-.0148^{* b}$ \\
\hline
\end{tabular}

Note.-Panel A presents the mean equity abnormal returns (ARs) for the sample of equity offerings broken down by portfolio sequence. Two-day unstandardized mean ARs are reported for the security announcements; however, all statistical tests involving ARs are performed using mean standardized prediction errors. Panel B compares the mean ARs for all possible pairwise portfolio combinations for the stock offerings. All cell entries in panel B represent the mean of the second portfolio value for the variable of interest less the mean of the first portfolio value in the numbered comparisons.

${ }^{a}$ Medians tests were also constructed for the AR variables with no qualitative change in results.

b The $D[\cdot]$ operator represents the difference between the means for the numbered portfolios for the variable in brackets. For example, the $D$ [abnormal return] for the 1-4 comparison represents the mean abnormal return of portfolio 4 minus the mean abnormal return for portfolio 1 . The sequential signaling hypothesis predicts the mean AR for portfolio 4 will be absolutely greater than the mean AR of portfolio 1. Since the mean AR for both portfolios are negative, the 1-4 comparison should be negative and significant.

* Significant at the $5 \%$ level.

** Significant at the $1 \%$ level. 
$-3.59 \%$ for portfolio 4 . The equity announcements provide negative information irrespective of the timing of other signals. Panel B of table 4 contains comparisons of differences in mean ARs between all possible portfolio combinations $(1-2,1-3,1-4,2-3,2-4,3-4)$ for the stock issue sample. Each comparison is made by subtracting the mean AR of the lower number portfolio from the mean of the higher number portfolio. Under the sequential timing hypothesis, the absolutely smallest abnormal returns are expected to occur in portfolio 1. Even though portfolio 3 exhibits the absolutely smallest mean AR in panel A, the difference between 1 and 3 is not significant. The sequential timing hypothesis also predicts that the absolute value of the portfolio 4 mean AR should be greater than any of the other portfolios since $B$ should be more informative when it precedes both $D$ and $X$. Hence, the comparisons 1-4, 2-4, and 3-4 should be negative and significant. Two of the three comparisons are negative and significant, while the comparison 2-4 is negative but not significant. The timing of the dividend signal appears to "condition" the stock offering abnormal return, while the timing of the prior release of the earnings signal does not.

The remaining comparisons will be significant only if information imparted by the prior dividend differs from information provided by the prior earnings. Comparison 2-3 is insignificant, though there is a $1.06 \%$ performance disadvantage when the dividend signal is last. This is of the same scale as the significant $1.07 \%$ difference for comparison 1-4. Even though not significant, the sign and size of the difference is consistent with comparisons 1-4 and 3-4. The delay of the dividend until after the equity announcement appears to be received more negatively than the delay of earnings.

Tukey joint tests also confirm the above results. The mean abnormal return is not different when earnings precede equity offers (portfolios 1 and 2) and earnings follow equity offers (portfolios 3 and 4). However, the null hypothesis of no difference in abnormal returns is rejected at the $5 \%$ level when dividends precede equity offers (portfolios 1 and 3) versus observations where dividends follow equity offers (portfolios 2 and 4).

A supplemental test is performed where tighter, or more restricted, pre- to postearnings and dividend announcement windows are examined. This test uses only (i) equity issues that had either a prior dividend and earnings announcement within 30 trading days of the issue announcement and no subsequent dividend and earnings announcement for 30 trading days after the issue announcement or (ii) issues that subsequently announced dividend and earnings within 30 trading days after the issue announcement and did not announce dividend or earnings for 30 trading days before the issue announcement. This restriction reduces the sample size to 91 observations. The choice of 30 days is somewhat arbitrary. Choosing a shorter interval such as 20 
days reduces the sample size from 91 to 63 observations. The four portfolios then have too few observations to detect differences in abnormal returns between portfolios.

Results for the reduced sample indicate that comparisons 1-4 and 3-4 are still significant at the 5\% level, while all other comparisons are insignificant. Timing of earnings appears to have limited effect on the information content of equity issues, while dividend timing affects equity offer abnormal returns. The abnormal return results are also compared with the findings of Korajczyk, Lucas, and McDonald. They report a weak statistical (albeit an economically significant) negative relationship between the length of time since the prior earnings release and the equity issue announcement. We calculate the number of trading days between the prior earnings and dividend announcements and the equity announcement for the refined sample and estimate the following regression model:

$$
\mathrm{SPE}_{i}=\alpha+\beta \mathrm{DBDP}_{i},
$$

where $\mathrm{DBDP}_{i}$ for observation $i$ is the minimum of (1) the number of trading days between the prior earnings announcement and the issue announcement or (2) the number of trading days between the prior dividend announcement and the issue announcement. The estimate of $\alpha$ is negative and significant at the 5\% level and the $\beta$ estimate is significantly negative at the $1 \%$ level, indicating that the longer the time interval since the last information release, the greater the stock price decline associated with an equity offering. By incorporating the dividend announcement into the prior information set, we are able to find a much stronger statistical relationship than Korajczyk, Lucas, and McDonald between the interval since the last information release and the equity offer abnormal return.

\section{B. Signal Sequence and Straight Debt Announcement Abnormal Returns}

The results for the debt sample in panel A of table 5 are supportive of the sequential signaling hypothesis. The mean ARs for portfolios 1, 2, and 3 when $D$ and/or $X$ precede $B$ are not significantly different from zero. In contrast, the mean AR for portfolio 4 , where $B$ is not partially revealed by either prior signal, is $-0.67 \%$ and is significant at the $1 \%$ level. An examination of portfolio medians provides similar results.

In panel B of table 5, differences between mean ARs for the debt portfolios are presented. The comparisons 1-4, 2-4, and 3-4 are all negative and significant at the $5 \%$ level, while $1-3$ is significant at the $10 \%$ level. A prior announcement of earnings, dividends, or both leads to insignificant mean ARs associated with the announcement of a debt offering. The Tukey joint tests provide evidence that the differences in ARs are primarily due to the timing of the dividend announcements. 
TABLE 5 Average Prediction Errors for Straight Debt Offers by Portfolio

A. Portfolio Mean Abnormal Returns: Debt Offers

\begin{tabular}{lcl}
\hline & $D$ Precedes $B$ & $D$ Follows $B$ \\
\hline$X$ precedes $B$ & Portfolio 1 & Portfolio 2 \\
Abnormal return $(\mathrm{AR})^{\mathrm{a}}$ & -.0011 & -.0009 \\
$X$ follows $B$ & Portfolio 3 & Portfolio 4 \\
Abnormal return $(\mathrm{AR})^{\mathrm{a}}$ & -.0029 & $-.0067^{* * *}$ \\
\hline
\end{tabular}

B. Comparisons of Portfolio Mean Abnormal Returns: Debt Offers

\begin{tabular}{|c|c|c|c|}
\hline \multirow{5}{*}{ 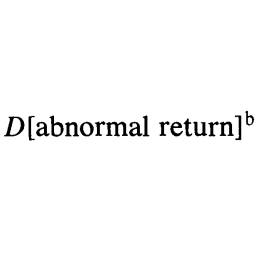 } & \multicolumn{3}{|c|}{ Portfolio Comparisons } \\
\hline & $1-2$ & $1-3$ & $1-4$ \\
\hline & .0002 & $-.0018^{*}$ & $-.0056^{* *}$ \\
\hline & \multicolumn{3}{|c|}{ Portfolio Comparisons } \\
\hline & $2-3$ & $2-4$ & $3-4$ \\
\hline 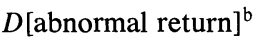 & -.0020 & $-.0058^{* *}$ & $-.0038^{* * *}$ \\
\hline
\end{tabular}

Note.-Panel A presents the mean equity abnormal returns (ARs) for the sample of debt offerings broken down by portfolio sequence. Two-day unstandardized mean ARs are reported for the security announcements; however, all statistical tests involving ARs are performed using mean standardized prediction errors. Panel B compares the mean ARs for all possible pairwise portfolio combinations for the stock offerings. All cell entries in panel B represent the mean of the second portfolio value for the variable of interest less the mean of the first portfolio value in the numbered comparisons.

${ }^{a}$ Medians tests were also constructed for the AR variables with no qualitative change in results.

b The $D[\cdot]$ operator represents the difference between the means for the numbered portfolios for the variable in brackets. For example, the $D$ [abnormal return] for the 1-4 comparison represents the mean abnormal return of portfolio 4 minus the mean abnormal return for portfolio 1 . The sequential signaling hypothesis predicts the mean AR for portfolio 4 will be absolutely greater than the mean AR of portfolio 1. Since the mean AR for both portfolios are negative, the 1-4 comparison should be negative and significant.

* Significant at the $10 \%$ level.

$* *$ Significant at the $5 \%$ level.

*** Significant at the $1 \%$ level.

This result is consistent with our evidence on equity offer announcements. Abnormal returns do not differ based on whether earnings precede (portfolios 1 and 2) or follow (portfolios 3 and 4) debt offers. When dividends follow debt offers (portfolios 2 and 4), the debt offer announcement results in a significantly more negative mean AR than when dividends precede debt offers (portfolios 1 and 3).

A supplemental test examines debt issues having less than 30-day "prior" versus less than 30-day "post" dividend and earnings announcements. Results are qualitatively similar to the results in panel B of table 5, except the 1-3 comparison is no longer marginally significant.

Equation (4) is also estimated for the refined debt sample. The estimated intercept is significantly positive and the slope estimate is sig- 
nificantly negative (at the $5 \%$ and $1 \%$ level, respectively). ${ }^{10}$ The debt offers SPEs are, on average, positive for short intervals of up to 15 days, but decline with interval length.

A plausible implication is that a signal-to-issue debt, if devoid of earnings and dividend information content, is received positively. Investors interpret the news that the firm is seeking debt financing less favorably the longer the time interval between the last information release and the debt offer announcement. ${ }^{11}$ Tests of differences in medians do not change the conclusions for either the debt or equity sample. ${ }^{12}$

\section{Signal Sequence and Dividend and Earnings Changes}

First, the positive and negative dividend and earnings changes are examined to determine whether the announcements are distributed evenly across the timing sequences. A two-way contingency table and a chi-square test are constructed to examine whether the sign of the dividend change is associated with the sequence of the dividend announcement relative to the security announcement. Results are presented in panel A of table 6. The null hypothesis of no association between the two partial sequences, $D$ precedes $B$ and $D$ follows $B$, and the sign of the dividend change is rejected at the $5 \%$ level for the stock sample. There are a greater than expected number of negative dividend changes and fewer dividend increases when $D$ follows $B$. Additionally, a greater than expected number of dividend increases and fewer dividend decreases occur when $D$ precedes $B$. This result is consistent with managerial behavior implied by John and Williams (1985). The null hypothesis of no association cannot be rejected for the sample of debt issues in panel B of table 6 .

Test results of the association of the timing of $X$ relative to $B$ and the sign of the earnings change are presented in panels $C$ and $D$ of table 6. The null hypothesis of no association between the partial sequences, $X$ precedes $B$ and $X$ follows $B$, and the sign of $X^{u}$ cannot be rejected for either the debt or stock samples. The lack of effect of the timing of the earnings signal provides supplemental evidence that

10. Use of 20- and 10-day intervals for the debt sample does not affect conclusions.

11. Equation (4) tests rest on a problematic assumption of the nature of information arrival. The linear functional form of eq. (4) implies that this is a joint test of signal timing and uniform information arrival over time. Major information revisions are likely to be more frequent in some periods and less frequent or absent in others. For example, Brous (1992) observes that analysts' earnings forecasts are typically updated infrequently, usually some time after a major information release. Although we find a significant relationship with eq. (4) for both samples, the binary tests, such as the prior/ postclassification tests, are less restrictive and potentially more appropriate.

12. In supplemental tests, the sign of earnings and dividend changes are not related to the offer SPE within each portfolio in either the debt or equity offer samples. The effect is apparently a timing phenomenon. 
TABLE 6 Association of the Sign of Dividend and Earnings Changes to Timing of Announcements

A. Dividends and Equity Announcements

\begin{tabular}{|c|c|c|c|c|}
\hline \multirow[b]{2}{*}{ Timing } & \multicolumn{3}{|c|}{ Sign of Dividend Change } & \\
\hline & - & + & 0 & \\
\hline$D$ follows $B$ & $\begin{array}{c}18 \\
(12)\end{array}$ & $\begin{array}{c}9 \\
(11)\end{array}$ & $\begin{array}{l}58 \\
(62)\end{array}$ & $\begin{array}{l}\text { actual } \\
\text { (expected under null) }\end{array}$ \\
\hline$D$ precedes $B$ & $\begin{array}{c}9 \\
(15)\end{array}$ & $\begin{array}{l}15 \\
(13)\end{array}$ & $\begin{array}{c}82 \\
(78)\end{array}$ & $\begin{array}{l}\text { actual } \\
\text { (expected under null) }\end{array}$ \\
\hline
\end{tabular}

\section{B. Dividends and Debt Announcements}

\begin{tabular}{lcccl}
\hline & \multicolumn{3}{c}{ Sign of Dividend Change } & \\
\cline { 2 - 5 } Timing & - & + & 0 & \\
\hline$D$ follows $B$ & 13 & 35 & 183 & actual \\
& $(12)$ & $(38)$ & $(182)$ & $\begin{array}{l}\text { (expected under null) } \\
\text { actual } \\
\text { (expected under null) }\end{array}$ \\
& 17 & 59 & 272 & $(273)$ \\
$\chi^{2}=.4455$, insignificant $p$-value & & $(56)$ & &
\end{tabular}

\section{Earnings and Equity Announcements}

\begin{tabular}{lcc}
\hline & \multicolumn{2}{c}{ Sign of Earnings } \\
Change
\end{tabular}

\section{Earnings and Debt Announcements}

\begin{tabular}{lll}
\hline & \multicolumn{2}{c}{$\begin{array}{c}\text { Sign of Earnings } \\
\text { Change }\end{array}$} \\
\cline { 2 - 3 } Timing & - & + \\
\hline$X$ follows $B$ & 117 & 122 \\
& $(118)$ & $(121)$ \\
$X$ precedes $B$ & 170 & 170 \\
& $(169)$ & $(171)$ \\
$\chi^{2}=.0614$, insignificant $p$-value &
\end{tabular}

NoTE.-Panel A contains the signs of dividend changes disaggregated by dividends preceding and following equity announcements. Panel B contains the same information relative to dividends and debt announcements. Panel $C$ presents the relationship of the sign of earnings changes to the timing of equity announcements while panel $\mathrm{D}$ holds the distribution of earnings changes to debt announcement timing. The numbers in parentheses represent the expected frequencies in each cell that would exist under the null of no impact from timing. 
dividends are necessary to corroborate earnings, as in John and Williams (1985).

Table 7 compares the average dividend and earnings changes based on signal sequence. The tests of whether the $X^{u}$ are significantly different from zero in panel A of table 7 are based on tests of median changes. The Brown Mood median test is used to test for significant differences in portfolio medians for the $X$ variable in panel B of table 7. On average, significant decreases in dividends occur only in portfo- lios 2 and 4 in panel A of table 7 for the stock sample. In portfolios 1 and 3, where dividend releases precede the issue announcement, the average dividend change is insignificantly different from zero. An equity issue announced before the dividend indicates a greater likelihood that the later announced dividend will be decreased.

Comparisons between the portfolios in the equity sample also substantiate the dividend timing phenomenon. Negative differences in the mean dividend changes are found in comparisons 1-2, 1-4 (significant at the 5\% level), and 3-4 (significant at the 10\% level) in the stock sample in panel B of table 7. On average, dividend decreases are larger when the dividend announcement is postponed until after the security issue announcement.

The sign of comparison 2-3 leads to the same conclusion. When managers announce only earnings and not dividends before the security issue announcement, investors revise upward their expectations of the likelihood of a dividend decrease. Managers appear to postpone bad news until after the offering. ${ }^{13}$ Investors also seem to be aware of this timing phenomenon.

The significant mean dividend increase found in portfolio 3 relative to portfolio 1 of the stock sample also may represent managerial timing of dividend increases relative to the security announcement in order to ameliorate the negative effect of the issue before reporting a relative (nonsignificant) change in earnings of $-2.38 \%$. Investors appear to react as John and Williams (1985) suggest.

Next, the effect of timing of earnings announcements relative to common stock issue announcements is considered. In panel A of table 7, significant increases in earnings are found only in portfolios 1 and 2. The earnings announcement precedes the issue announcement in these portfolios. However, the comparisons in panel B demonstrate that there are no significant differences in earnings changes regardless of the timing of the earnings announcement. The effect on the offer AR of delaying the earnings release is also not as negative as the effect

13. The mean number of days from the announcement to the subsequent dividend (earnings) announcement after adjusting for outliers is 36 (33) days. Mikkelson and Partch (1986) report a median of 16 days from offer announcement to completion; hence, most offers are probably completed prior to the subsequent earnings and dividend announcement. 
TABLE 7 Average Dividend and Earnings Change around Equity and Debt Offers

A. Portfolio Mean Dividend and Earnings Change: Debt and Equity

\begin{tabular}{lcc}
\hline & $D$ Precedes $B$ & $D$ Follows $B$ \\
\hline$X$ precedes $B$ & Portfolio 1 & Portfolio 2 \\
Equity dividend change $\left(D^{u}\right)$ & -.0149 & $-.1016^{* *}$ \\
Equity earnings change $\left(X^{u}\right)^{\mathrm{a}}$ & $.1071^{* * *}$ & $.0707^{* *}$ \\
Debt dividend change $\left(D^{u}\right)$ & .0265 & .0091 \\
Debt earnings change $\left(X^{u}\right)$ & .0001 & .0486 \\
& & \\
$X$ follows $B$ & Portfolio 3 & Portfolio 4 \\
Equity dividend change $\left(D^{u}\right)$ & .1636 & $-.0728^{* *}$ \\
Equity earnings change $\left(X^{u}\right)$ & .0833 & .0920 \\
Debt dividend change $\left(D^{u}\right)$ & .0299 & .0029 \\
Debt earnings change $\left(X^{u}\right)$ & -.0198 & .0258 \\
\hline
\end{tabular}

B. Comparison of Portfolio Mean Dividend and Earnings Changes: Debt and Equity

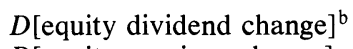

$D$ [equity earnings change]

$D$ [debt dividend change]

$D$ [debt earnings change]

$D$ [equity dividend change $]^{\mathrm{b}}$

$D$ [equity earnings change]

$D$ [debt dividend change]

$D$ [debt earnings change]

\begin{tabular}{ccc}
\multicolumn{3}{c}{ Portfolio Comparisons } \\
\hline $1-2$ & $1-3$ & $1-4$ \\
\hline$-.0867^{* *}$ & $.1785^{*}$ & $-.0579^{* *}$ \\
.0600 & -.0238 & -.0150 \\
-.0174 & .0034 & -.0236 \\
.0485 & -.0199 & .0259 \\
\hline \multicolumn{3}{c}{ Portfolio Comparisons } \\
\hline $2-3$ & $2-4$ & $3-4$ \\
\hline $.2652^{*}$ & .0288 & $-.2364^{*}$ \\
.0126 & .0213 & .0087 \\
.0208 & -.0062 & -.0270 \\
-.0684 & -.0228 & .0456
\end{tabular}

Note.-Panel A presents the mean dividend $\left(D^{u}\right)$ and earnings $\left(X^{u}\right)$ changes broken down by portfolio sequence for the debt and equity offers. Panel B compares the mean dividend and earnings changes for all possible pairwise portfolio combinations. With four portfolios, there are six possible combinations taken two at a time. All cell entries in panel B represent the mean of the second portfolio value for the variable of interest less the mean of the first portfolio value in the numbered comparisons.

a The calculation of $X^{u}$ results in large outliers due to division by $X_{q-1}$, which are close to zero. This may distort means tests. The results in this table involving earnings utilize medians. Tests on $D^{u}$ and $D\left[D^{u}\right]$ using medians yield results qualitatively similar to those presented. We replicated the tests after eliminating dividend and earnings outliers; the significance levels of these variable drops slightly but no other material changes occur.

b The $D[\cdot]$ operator represents the difference between the means for the numbered portfolios for the variable in brackets. For example, the $D[\cdot]$ for the $1-4$ comparison represents the mean dividend or earnings change of portfolio 4 minus the mean dividend or earnings change for portfolio 1 .

* Significant at the $10 \%$ level.

** Significant at the $5 \%$ level.

*** Significant at the $1 \%$ level. 
of postponing the dividend announcement. ${ }^{14}$ For the debt sample, the mean dividend and earnings changes are insignificantly different from zero in all four portfolios, and there are no significant differences in the average dividend or earnings changes in any portfolio.

\section{Conclusions}

Investors react to security offers in a manner consistent with the implications of signaling models provided by John and Williams (1985) and Korajczyk, Lucas, and McDonald (1991). Generally, the earlier the security issue announcement in the set of three announcements, the greater is its negative value effect. Managers should be aware that not only the signal content but also the timing of the signal affects how investors will react to a given information release.

Most equity and straight debt issue announcements are made shortly after earnings and dividend releases. However, managers are more likely to announce an equity issue before a dividend decline. Regardless of signal sequence, equity issue announcements are interpreted as bad news by investors. However, the abnormal return differences indicate that investors discount the stock price more heavily when the equity issue announcement precedes the dividend release. This justifiable response is related to a higher probability of receiving "bad" dividend news. This suggests a possible separating equilibrium between better and weaker firms. Better performing firms seem to be able to differentiate themselves from weaker firms by announcing positive or zero dividend changes prior to an equity offer announcement. Superior performing firms would then mitigate the agency costs arising from the lemons phenomenon proposed by Myers and Majluf (1984) by releasing current period cash flow information before the offer announcement.

This type of timing behavior is not observed around straight debt offer announcements. However, the information content of a debt offer announcement still does vary based on the sequence of signals. Sig-

14. As a check on our assumption of a naive expectations model for earnings and dividends, we also estimated $X^{u}$ and $D^{u}$ by calculating the standardized abnormal returns for the dividend and earnings announcements. Using ordinary least squares, we tested whether these proxy measures of the unexpected earnings and dividends differed among the portfolios. No significant differences were found. This is consistent with an efficient market. This implies that the timing of security offering announcements provides the distinguishing value affecting marginal information in this set of three signals. We also tested for differences in informativeness using the absolute value of the standardized dividend and earnings ARs and found no difference. Compared to table 7 results, however, we should have at least found a significant positive AR for earnings in portfolio 1 if our observed table 7 unexpected earnings were truly unexpected by investors. Possibly, the greater noise in the AR measure may contribute to the difference in results. Similar to Loderer and Mauer (1992), we found no relationship between signal sequence and Miller and Rock's net dividend measure. 
nificant negative abnormal returns occur for straight debt offers only when the offer announcement closely precedes both the current earnings and dividend releases.

\section{Appendix}

\section{Partially Revealing Signals in a Miller and Rock Environment}

We first examine the signaling problem in a single-period decision environment with investment $(I)$ known, similar to the case presented in the Miller and Rock (1985) model. This framework is useful because it provides a simple structure for establishing the conditional informativeness of a given announcement such as dividends or earnings. In their model, the dividend announcement $(D)$ and the external financing announcement $(B)$ are implicitly revealed simultaneously. The revelation of either $D$ or $B$ alone provides no information until the second signal is received. Since investment is known, the two signals allow investors to deduce earnings $(X)$ via the cash flow identity. In reality, firms often do not simultaneously announce $D$ and $B$. We hypothesize that the occurrence of either signal alone modifies the expectations concerning the remaining signal(s).

Prior to any announcements (time 0 ), the expected sources and uses of a firm are given by

$$
E_{0}(X \mid \phi)-I=E_{0}(D \mid \phi)-E_{0}(B \mid \phi),
$$

where $E_{0}(\cdot)$ is the time 0 expectation of $(\cdot)$ conditional on some prior information set $\phi$. All announcements will be disclosed by the end of the investment period $T$. Reformulating equation (A1) in terms of unexpected changes yields

$$
X^{u}=D^{u}-B^{u},
$$

for $i=1,2, \ldots, N$, where $i$ represents a possible announcement date of the $N$ possible announcement dates to and including $T$. Over the $N$ possible dates, there is one announcement each of $X, D$, or $B$. The superscript $u$ represents the shift in the expected value $E_{i}(\cdot)-E_{i-I}(\cdot)$, for $X, D$, or $B$, at date $\dot{i}$. Although management may receive information at any time, asymmetrically informed investors revise expected values only when $X, D$, or $B$ are announced.

Proceeding in this modified Miller and Rock framework, partially revealing information on earnings occurs when the signals $D$ or $B$ (but not both) precede $X$. These sequences include $(D-X-B),(D-[X B]),(B-X-D)$, and $(B-[X D])$, where the brackets enclose simultaneous announcements. An examination of the first two cases where the dividend announcement precedes the earnings announcement is sufficient to clarify the notion of partially revealing signals. With an announcement of dividends at time $i$,

$$
D^{u}=X^{u}+B^{u},
$$

where $D^{u}$ is now known. The sources and uses identity is only maintained if

$$
X^{u}=\delta D^{u}
$$


and

$$
B^{u}=(1-\delta) D^{u},
$$

where $\delta$ represents the proportion of the unexpected dividend attributed to an unexpected shift in earnings and $(1-\delta)$ represents the proportion attributed to an unexpected shift in external financing. Thus, both a shift in earnings expectations, $X^{u}$, and a shift in expectations of external financing, $B^{u}$, will occur for $\delta$ not equal to zero or one. The lower the $\delta$, the greater the responsiveness of $B^{u}$ to an unexpected change in dividends. With an announced change in earnings, equation (A2) holds where

$$
D^{u}=\tau X^{u}
$$

and

$$
B^{u}=-(1-\tau) X^{u}
$$

Our empirical tests determine if $(1-\delta)$ and $(1-\tau)$ differ from zero. The $\delta(\tau)$ could shift over time in a multiperiod framework, as long as $\delta(\tau)$ does not equal zero or unity, preceding dividend or earnings announcements would partially reveal $B^{u}$. The single-period assumption considered here is violated by firms that have lives that extend beyond the current period. In this case, the final signal in the sequence would not be redundant since the announcement will still provide information about future expected cash flows. Consequently, the last signal in the sequence may still have a valuation effect.

The partially revealing signal concept may also be easily applied to an environment where investment is unknown. Prior to any announcements, the conditional expectations of $B, D, X$, and $I$ are based on some common information set $\phi$. Let the first announcement in the sequence be $X$. The announcement of earnings will potentially affect the conditional expectations of the remaining signals by adding to the information set $\phi$. Originally, the expectation of $B$ $(E[B \mid \phi])$ is conditional only on $\phi$. After the earnings announcement, the conditional expectation of $B$ is now $E[B \mid \phi, X]$. In this case, $X^{u}=D^{u}-B^{u}+I^{u}$ must hold to preserve the cash flow identity. It must also be true that $D^{u}=$ $w_{1} X^{u},-B^{u}=w_{2} X^{u}$, and $I^{u}=w_{3} X^{u}$, where $\Sigma w_{i}=1$. More important, the sequential timing hypothesis would still hold.

Kane, Lee, and Marcus (1984) and Healy and Palepu (1988) provide evidence that $\delta$ (or $\tau$ ) is nonzero for the case of earnings and dividend announcements since they find that these two announcements provide corroborative information. If $(1-\tau)$ is nonzero, the announcement date abnormal return associated with $B$ will differ based on whether $X$ has been previously announced. In this framework, the abnormal return associated with the security announcement is conditionally dependent on the occurrence of other information releases.

\section{References}

Aharony, J., and Swary, I. 1980. Quarterly dividend and earnings announcements and stockholder returns: An empirical analysis. Journal of Finance 35 (March): 1-12. 
Ambarish, R.; John, K.; and Williams, J. 1987. Efficient signalling with dividends and investments. Journal of Finance 42 (June): 321-43.

Asquith, P., and Mullins, D. W., Jr. 1983. The impact of initial dividend payments on shareholder wealth. Journal of Business 56 (January): 77-96.

Asquith, P., and Mullins, D. W., Jr. 1986. Equity issues and stock price dilution. Journal of Financial Economics 15 (January/February): 61-90.

Ball, R., and Brown, P. 1968. An empirical evaluation of accounting income numbers. Journal of Accounting Research 6 (Autumn): 159-78.

Brickley, J. A. 1983. Shareholder wealth information signaling and the specially designated dividend: An empirical study. Journal of Financial Economics 12 (August): 187-209.

Brous, P. A. 1992. Common stock offerings and earnings expectations: A test of the release of unfavorable information. Journal of Finance 47 (September): 1517-36.

Charest, G. 1978. Dividend information, stock returns and market efficiency II. Journal of Financial Economics 6 (June/September): 297-330.

Dierkens, N. 1991. Information asymmetry and equity issues. Journal of Financial and Quantitative Analysis 26 (June): 181-99.

Eades, K.; Hess, P.; and Kim, E. 1985. Market rationality and dividend announcements. Journal of Financial Economics 14 (December): 581-604.

Eckbo, B. E. 1986. Valuation effects of corporate debt offerings. Journal of Financial Economics 15 (January/February): 119-51.

Fehrs, D. H.: Benesh, G. A.; and Peterson, D. R. 1988. Evidence of a relation between stock price reactions around cash dividend changes and yields. Journal of Financial Research 11 (Summer): 111-23.

Handjinicolaou, G., and Kalay, A. 1984. Wealth redistributions or changes in firm value: An analysis of return to the stockholders and bondholders around dividend announcements. Journal of Financial Economics 13 (March): 35-63.

Hansen, R., and Crutchley, C. 1990. Corporate earnings and financings: An empirical analysis. Journal of Business 63 (July): 347-71.

Healy, P., and Palepu, K. 1987. Equity offerings as earnings signals. Working paper. Cambridge, Mass.: Massachusetts Institute of Technology and Harvard University.

Healy, P., and Palepu, K. 1988. Earnings information conveyed by dividend initiations and omissions. Journal of Financial Economics 21 (September): 149-75.

Healy, P., and Palepu, K. 1990. Earnings and risk changes surrounding primary stock offers. Journal of Accounting Research 28 (Spring): 25-48.

John, K., and Williams, J. 1985. Dividends, dilution and taxes: A signalling equilibrium. Journal of Finance 40 (September): 1053-70.

Johnston, J. 1984. Econometric Methods. 3d ed. New York: McGraw-Hill.

Kalay, A., and Loewenstein, U. 1985. Predictable events and excess returns: The case of dividend announcements. Journal of Financial Economics 14 (September): 423-49.

Kalay, A., and Shimrat, A. 1987. Firm value and seasoned equity issues: Price pressure, wealth redistribution, or negative information. Journal of Financial Economics 19 (September): 109-26.

Kane, A.; Lee, Y. K.; and Marcus, A. 1984. Earnings and dividend announcements: Is there a corroboration effect. Journal of Finance 39 (September): 1091-99.

Korajczyk, R. A.; Lucas, D.; and McDonald, R. 1991. The effect of information releases on the pricing and timing of equity issues: Theory and evidence. Review of Financial Studies 4 (Winter): 685-708.

Kross, W., and Schroeder, D. 1984. An empirical investigation of the effect of quarterly earnings announcement timing on stock returns. Journal of Accounting Research 22 (Spring): 153-76.

Kwan, C. C. Y. 1981. Efficient market tests of the information content of dividend announcements: Critique and extension. Journal of Financial and Quantitative Analysis 16 (June): 193-206.

Lang, L., and Litzenberger, R. 1989. Dividend announcements: Cash flow signalling vs. free cash flow hypothesis? Journal of Financial Economics 24 (September): 181-91.

Loderer, C., and Mauer, D. C. 1992. Corporate dividends and seasoned equity issues: An empirical investigation. Journal of Finance 47 (March): 201-25. 
Masulis, R. W., and Korwar, A. N. 1986. Seasoned equity offerings. Journal of Financial Economics 15 (January/February): 91-118.

Mikkelson, W. H., and Partch, M. M. 1986. Valuation effects of security offerings and the issuance process. Journal of Financial Economics 15 (January/February): 31-60. Miller, M. H., and Rock, K. 1985. Dividend policy under asymmetric information. Journal of Finance 40 (September): 1031-51.

Myers, S. C., and Majluf, N. S. 1984. Corporate financing and investment decisions when firms have information that investors do not have. Journal of Financial Economics 13 (June): 187-221.

Penman, S. H. 1987. The distribution of earnings news over time and seasonalities in aggregate stock returns. Journal of Financial Economics 18 (June): 199-228.

Rendleman, R. J., Jr.; Jones, C. P.; and Latane, H. A. 1982. Empirical anomalies based on unexpected earnings and the importance of risk adjustments. Journal of Financial Economics 10 (November): 269-87.

Trueman, B. 1990. Theories of earnings-announcement timing. Journal of Accounting and Economics 13 (October): 285-301.

Verrecchia, R. 1990. Information quality and discretionary disclosure. Journal of Accounting and Economics 12 (March): 365-80. 